\title{
BMJ Open Association of socioeconomic status measured by education, and cardiovascular health: a population-based cross-sectional study
}

\author{
Slavenka Janković, ${ }^{1}$ Dragana Stojisavljević, ${ }^{2}$ Janko Janković, ${ }^{3}$ Miloš Erić, ${ }^{4}$ \\ Jelena Marinković ${ }^{5}$
}

To cite: Janković S, Stojisavljević D, Janković J, et al. Association of socioeconomic status measured by education, and cardiovascular health: a population-based cross-sectional study. BMJ Open 2014;4:e005222. doi:10.1136/bmjopen-2014005222

- Prepublication history and additional material is available. To view please visit the journal (http://dx.doi.org/ 10.1136/bmjopen-2014005222)

Received 12 March 2014 Revised 20 June 2014 Accepted 23 June 2014

CrossMark

For numbered affiliations see end of article.

Correspondence to: Dr Slavenka Janković; slavenkaj@gmail.com

\section{ABSTRACT}

Objective: Cardiovascular health (CVH) is a relatively new concept defined by the American Heart Association (AHA). The aim of the present study was to assess whether the indices of CVH were discriminators of socioeconomic status (SES) in the adult population of the Republic of Srpska (RS).

Design: Population-based cross-sectional study.

Setting: RS, Bosnia and Herzegovina.

Participants: The study involved 4165 adults aged $\geq 18$ years (mean age $50.2 ; 54 \%$ women) who participated in the National Health Survey performed from September to November 2010 in the RS.

Study variables: Participant's education was a proxy for SES. Potential discriminators of SES were indices of $\mathrm{CVH}$ presented according to AHA as: ideal health behaviours index (non-smoking, body mass index $<25 \mathrm{~kg} / \mathrm{m}^{2}$, physical activity at goal level and healthy diet); ideal health factors index (untreated total cholesterol $<200 \mathrm{mg} / \mathrm{dL}$, untreated blood pressure $<120 /<80 \mathrm{~mm} \mathrm{Hg}$, untreated fasting glucose $<100 \mathrm{mg} / \mathrm{dL}$ and non-smoking); and ideal CVH status (defined as all seven ideal health metrics present) versus intermediate and poor CVH status.

Results: Participants with high educational levels had a significantly greater number of ideal CVH metrics, and ideal health factor metrics compared with those with low or medium educational level (OR $0.8895 \% \mathrm{Cl}$ 0.77 to 0.99 and $\mathrm{OR} 0.8895 \% \mathrm{Cl} 0.80$ to 0.96 ; $\mathrm{OR}$ $0.8195 \% \mathrm{Cl} 0.69$ to 0.96 and OR $0.7795 \% \mathrm{Cl} 0.68$ to 0.87 ; respectively). The number of ideal behaviour metrics was not a discriminator of educational groups. Concerning the categories of $\mathrm{CVH}$ status the poor $\mathrm{CVH}$ was a discriminator for low and medium education compared with those with high education (OR 1.93 $95 \% \mathrm{Cl} 1.24$ to 3.01 and OR $1.5495 \% \mathrm{Cl} 1.08$ to 2.19 , respectively).

Conclusions: Our findings emphasise the large potential for preventing cardiovascular disease, showing a low proportion with a favourable $\mathrm{CVH}$ profile, especially among low-educated people. It is necessary to consider prevention strategies aimed at improving $\mathrm{CVH}$ in RS, targeting primarily low educational groups.

\section{Strengths and limitations of this study}

- The main strength of this study is the large sample representative of the adult population of Republic of Srpska aged $\geq 18$ years.

- The cross-sectional design of the study makes it difficult to judge causal relations.

- Another limitation is that education was used as the only indicator of socioeconomic status.

- Information regarding several cardiovascular health metrics (smoking, physical activity and diet) and educational level was self-reported which may be subject to recall bias.

\section{INTRODUCTION}

Cardiovascular disease (CVD) is the number one cause of death globally ${ }^{1}$ and estimates indicate that nearly 23.3 million people will die from CVD by $2030 .{ }^{2}$ Over $80 \%$ of CVD deaths take place in low-income and middle-income countries. ${ }^{1}$

In the Republic of Srpska (RS), one of the two autonomous entities that constitute Bosnia and Herzegovina, a European country still in the process of transition, CVD is the leading cause of death and disability, with a steady increase in CVD mortality. In 2010, CVD was responsible for $53 \%$ of all causes of death. $^{3}$

Recent recommendations from the American Heart Association (AHA) aim to improve cardiovascular health $(\mathrm{CVH})$ by encouraging people to meet the seven ideal CVH metrics: no smoking; being physically active; maintaining a healthy body weight; eating a healthy diet and having normal blood pressure, blood glucose and total cholesterol (TC) levels. ${ }^{4}$ Various cohort studies have demonstrated that meeting a greater number of ideal CVH metrics is associated with a lower risk of general mortality, CVD mortality ${ }^{5}$ and the risk of cardiovascular 
events. ${ }^{6}$ Developing effective methods of increasing ideal and decreasing poor CVH metrics should be a top priority in CVD prevention. However, to our knowledge, studies examining CVH metrics at the population level in European countries are limited.

It is well-known that CVD is patterned by socioeconomic status (SES), being more common in lower social classes, and that closing the gap between low and high socioeconomic groups offers great potential for reducing GVD mortality. ${ }^{7} 8$ Identifying populations with poor CVH may help inform public health policies and direct interventions towards those populations disproportionately affected, which may increase CVH and decrease CVD mortality. Therefore, the aim of the present study was to investigate whether the indices of $\mathrm{CVH}$ were discriminators of SES in the adult population of RS.

\section{METHODS}

\section{Study design and participants}

Data were taken from the 2010 National Health Survey in RS, Bosnia and Herzegovina, performed from September to November, 2010. To assure that the sample of the civilian adult population is nationally representative a two-stage stratified sampling was used. The first stage units were enumeration districts stratified by type of settlement (urban and rural) and five geographical regions. The second stage units were the households. Of 1866 households randomly selected for the sample, 1779 were interviewed with a response rate of $95.3 \%$. In the interviewed households 4673 adults were identified, of which 4165 were interviewed yielding a response rate of $89.1 \%$.To be enrolled, individuals had to be aged $\geq 18$ years, and needed to reside in RS for at least 1 year. Persons living in collective households and in institutions (homes for older people, hospitals and prisons) were excluded. The study was approved by the Ethics Committee of the Public Health Institute of RS. It conformed to the principles of the Declaration of Helsinki. Written informed consent was obtained for all participants.

All participants were interviewed and underwent physical examinations (anthropometric and blood pressure measurements, and blood tests) at their homes by welltrained public health workers.

\section{Study variables}

Demographic and socioeconomic characteristics (age, sex, marital status, education, employment status and type of settlement) of all participants were collected. Study participants also reported their smoking status, physical activity, diet, individual medical history of CVD, and drug treatment for hypertension, diabetes mellitus and hypercholesterolaemia. Marital status was categorised into two groups: married or living with partner and unmarried, divorced or widowed. SES was measured by education. Education levels were categorised as low (no schooling, incomplete primary education and primary education), medium (3 or 4 years of secondary education) and high (college and university education). Employment status was defined by one of three groups: employed, unemployed and inactive (retired, people attending some form of education, housewives, persons who are inactive due to family reasons, and people who are ill, unable to work or elderly). Type of settlement was identified at survey level as urban or rural. Smoking status was categorised as never-smoker, former smoker and current smoker.

Physical activity in this study was measured with a question: "In your leisure time, how often do you do physical exercise for at least $30 \mathrm{~min}$ which makes you at least mildly short of breath or perspire?" The response alternatives were (1) daily, (2) 4-6 times a week, (3) 2-3 times a week, (4) once a week, (5) 2-3 times a month, (6) a few times a year or less and (7) I cannot exercise because of illness/disability. Those who participated in physical activity four times or more per week (response alternatives 1 and 2) were categorised as active, those who exercised less than 4 times a week but at least 2-3 times a month (response alternatives 3-5) were categorised as moderately active and those who exercised several times a year or did not exercise at all were categorised as inactive (response alternatives 6 and 7).

For assessment of dietary intake we used a validated 25-item self-administered food frequency questionnaire (FFQ). ${ }^{9}{ }^{10}$ Each of the three items regarding fruit and vegetable consumption had a choice of six frequency categories ranging from 'never' to 'two or more times per day'. For all other food groups, each of the 22 items had a choice of four frequency categories ranging from 'never' to 'six or seven times per week'. Since FFQ assessed only usual frequency of intake of food and beverages over the previous week, but did not include information on portion sizes, each eating occasion was assumed to represent consumption of one serving of the food. We also used a validated food habits questionnaire consisting of 10 questions. ${ }^{9}{ }^{10}$ For the purpose of this study a healthy diet score (HDS) was developed. It consists of 11 indicators identified for each dietary guideline with the development of cut-offs and food groupings guided by the dietary guidelines for RS adults. ${ }^{11}$ Each of the 11 indicators had a defined minimum and maximum score. Vegetables and fruits group had a score range of 0-4 each. Protein group (meat, fish, eggs, nuts and legumes) and cereals and their products group each had a range of 0-6. Low-fat milk group and related products had a score of $0-3$, while fats and alcohol group had scores of 0-2 each. Consumption of high saturated fat, low nutrient density foods, so-called 'junk food' had a score of $0-4$ as well as the consumption of sweets and sugary drinks. Use of salt and regular meals ranged from 0 to 1 and 0 to 2 , respectively. The total HDS was the sum of 11 items and had a possible range of $0-38$, with a higher score reflecting increased compliance with the dietary guidelines (see online supplementary appendix 1). 
A portable electronic medical scale (Seca, 877) was used to measure body weight to the nearest halfkilogram. Standing body height $(\mathrm{cm})$ was measured to the nearest $0.1 \mathrm{~cm}$ with a portable wall-mounted stadiometer (Seca, 206). The body mass index (BMI) was calculated as weight in kilograms divided by squared height in metres $\left(\mathrm{kg} / \mathrm{m}^{2}\right)$. Systolic blood pressure (SBP, $\mathrm{mm} \mathrm{Hg}$ ) and diastolic blood pressure (DBP, $\mathrm{mm} \mathrm{Hg}$ ) were measured using mercury sphygmomanometer-diplomat-presameter (Riester, CE 0124, Germany) and cuffs of three sizes according to arm circumference, after the participants had been resting in a sitting position for at least $10 \mathrm{~min}$. Sitting blood pressure was measured three times after a 5 min rest. The mean of the last two measurements was used for the analysis. As recommended for developing countries, fasting blood glucose (FBG, $\mathrm{mg} / \mathrm{dL}$ ) and $\mathrm{TC}$ $(\mathrm{mg} / \mathrm{dL})$ were measured from early-morning capillary blood samples, ${ }^{12}{ }^{13}$ after an overnight fast. The samples were obtained and analysed at home using a calibrated Accutrend Plus GCTL analyser (Roche Diagnostics, Germany).

\section{CVH status}

The seven metrics proposed by the AHA were used for evaluating the CVH status of the participants. ${ }^{4}$ In accordance with AHA, metrics were classified into 'ideal', 'intermediate' or 'poor' as the following: (1) smoking: ideal (never or quit $>1$ year), intermediate (former, quit $\leq 1$ year) and poor (current); (2) BMI: ideal $\left(<25 \mathrm{~kg} / \mathrm{m}^{2}\right)$, intermediate $\left(25-29.9 \mathrm{~kg} / \mathrm{m}^{2}\right)$ and poor $\left(\geq 30 \mathrm{~kg} / \mathrm{m}^{2}\right)$; (3) physical activity: ideal (active), intermediate (moderately active) and poor (inactive); (4) diet: ideal (HDS $\geq 26$ points), intermediate (HDS 21-25 points) and poor (HDS <21 points); (5) TC: ideal $(<200 \mathrm{mg} / \mathrm{dL}$, untreated), intermediate (200-239 $\mathrm{mg} / \mathrm{dL}$ or treated to goal) and poor $(\geq 240 \mathrm{mg} / \mathrm{dL})$; (6) blood pressure: ideal (SBP $<120 \mathrm{~mm} \mathrm{Hg}$ and DBP $<80 \mathrm{~mm} \mathrm{Hg}$, untreated), intermediate (SBP 120-139 $\mathrm{mm} \mathrm{Hg}$ or DBP $80-89 \mathrm{~mm} \mathrm{Hg}$, or treated to goal) and poor (SBP $\geq 140 \mathrm{~mm} \mathrm{Hg}$ or DBP $\geq 90 \mathrm{~mm} \mathrm{Hg}$ ); and (7) FBG: ideal $(<100 \mathrm{mg} / \mathrm{dL}$, untreated $)$, intermediate $(100-125 \mathrm{mg} / \mathrm{dL}$ or treated to goal) and poor $(\geq 126 \mathrm{mg} / \mathrm{dL})$. The ideal health behaviours index (score 0-4) corresponds to the number of ideal behaviours (smoking, BMI, physical activity and healthy diet). The ideal health factors index (score 0-4) corresponds to the number of ideal health factors (blood pressure, TC, FBG and smoking). Given the importance of abstinence from smoking and smoking cessation to health promotion, smoking appears in lists of health behaviours as well as health factors. 'Ideal' CVH was defined as the simultaneous presence of seven CVH metrics. ${ }^{4}$ For 'intermediate' CVH (at least 1 of 7 health metrics at intermediate level and no poor health metrics) and 'poor' CVH (at least 1 of 7 health metrics at poor level) we used definition by Folsom $e t a l .{ }^{6}$

\section{Statistical analysis}

The analyses were carried out on 4165 participants except when indices of ideal CVH were in question. These analyses were performed on 4015 participants. We have excluded 150 participants, out of 4165 , who lacked data on any of the CVH health metrics.

Continuous variables were described by the means and $\mathrm{SD}$ or SE, and categorical ones with frequencies, percentages and $95 \%$ CIs.

Prevalence rates were estimated for indices of ideal $\mathrm{CVH}$, health behaviours and health factors for all participants, and separately for participants with low, medium and high education status. All reported estimates and 95\% CI were weighted using probability-sampling weights calculated to reflect an underlying population of inhabitants in RS in 2010.

Logistic regression analyses, as a classification tool, were used with adjustment according to age, sex, marital status, employment status and type of settlement where appropriate. The dependent variable was educational level (low vs medium, low vs high and medium vs high).

All statistical analyses were performed using SPSS V.20.0 software (SPSS Inc, Chicago, Illinois, USA) and STATA V.11.1 (StataCorp LP, College Station, Texas, USA) with the complex sampling design taken into account. Statistical significance was set at two-sided $\mathrm{p}<0.05$.

\section{RESULTS}

Our final analysis sample included 4165 participants (54\% women), which represents the adult population ( $\geq 18$ years) of the RS ( 1.16 million).

As shown in table $1,40.7 \%$ of all participants were classified in the low, $49.8 \%$ in the medium and $9.5 \%$ in the high education group. In comparison to participants with high education, those with low education were significantly older, more frequently women, rural dwellers, living without a partner, inactive or unemployed, with significantly higher levels of SBP, DBP and FBG. There were no significant differences between two groups in the levels of BMI and TC (table 1).

In comparison to the high education group, participants with medium education were significantly younger, more frequently rural dwellers, inactive or unemployed, with higher level of SBP and DBP (table 1).

A relative majority of participants $(41.2-76 \%)$ had ideal levels of $\mathrm{CVH}$ metrics, except for diet $(4.4 \%)$ and blood pressure (14.7\%; table 2). According to logistic regression analysis, participants with low education were significantly less frequently physically inactive, but more frequently had poor levels of HDS and SBP and DBP than participants with high education. In comparison to the high education group, participants with medium education were more frequently current smokers, more frequently had poor levels of diet score and poor or intermediate levels of blood pressures, but were less frequently physically inactive. There were no significant 
Table 1 Characteristics of study participants by educational level

\begin{tabular}{|c|c|c|c|c|c|c|c|}
\hline \multirow[t]{3}{*}{ Characteristics } & \multirow{3}{*}{$\begin{array}{l}\text { Total sample } \\
\mathrm{n}=4165\end{array}$} & \multicolumn{6}{|l|}{ Educational level } \\
\hline & & \multirow{2}{*}{$\begin{array}{l}\text { Low } \\
n=1694(40.7 \%)\end{array}$} & \multirow{2}{*}{$\begin{array}{l}\text { Medium } \\
n=2076(49.8 \%)\end{array}$} & \multirow{2}{*}{$\begin{array}{l}\text { High } \\
n=395 \text { (9.5\%) }\end{array}$} & \multicolumn{3}{|l|}{ ORs, $95 \% \mathrm{Cl}$, p value* } \\
\hline & & & & & Low vs medium & Low vs high & Medium vs high \\
\hline Age in years, mean (SD) & $50.19(17.59)$ & $60.21(15.84)$ & $42.68(14.98)$ & $46.69(16.36) \dagger$ & $\begin{array}{l}1.05(1.04 \text { to } 1.06) \\
0.000\end{array}$ & $\begin{array}{l}1.07(1.06 \text { to } 1.08) \\
0.000\end{array}$ & $\begin{array}{l}0.98(0.97 \text { to } 0.99) \\
0.000\end{array}$ \\
\hline \multicolumn{8}{|l|}{ Sex, n (\%) } \\
\hline Men‡ & $1917(46.0)$ & 558 (32.9) & $1134(54.6)$ & $225(57.0) \dagger$ & 1 & 1 & 1 \\
\hline Women§ & $2248(54.0)$ & $1136(67.1)$ & $942(45.4)$ & $170(43.0)$ & $\begin{array}{l}2.69(2.16 \text { to } 3.69) \\
0.000\end{array}$ & $\begin{array}{l}1.45(1.14 \text { to } 2.80) \\
0.000\end{array}$ & $\begin{array}{l}1.10(0.85 \text { to } 1.37) \\
0.392\end{array}$ \\
\hline Settlement, n (\%) & 4165 & 1694 & 2076 & 395 & & & \\
\hline Urban & $1725(41.4)$ & 404 (23.8) & $1044(50.3)$ & $277(70.1) \dagger$ & 1 & 1 & 1 \\
\hline Rural & $2440(58.6)$ & $1290(76.2)$ & $1032(49.7)$ & $118(29.9)$ & $\begin{array}{l}7.49(5.88 \text { to } 9.56) \\
0.000\end{array}$ & $\begin{array}{l}3.23(2.80 \text { to } 4.19) \\
0.000\end{array}$ & $\begin{array}{l}2.32(1.84 \text { to } 2.93) \\
0.000\end{array}$ \\
\hline Marital status, n (\%) & 4154 & 1691 & 2073 & 390 & & & \\
\hline Married or living with partner & $2738(65.9)$ & $1054(62.3)$ & $1432(69.1)$ & $252(64.6) \dagger$ & 1 & 1 & 1 \\
\hline Without partner & $1416(34.1)$ & $637(37.7)$ & $641(30.9)$ & $138(35.4)$ & $\begin{array}{l}1.10(0.88 \text { to } 1.39) \\
0.400\end{array}$ & $\begin{array}{l}1.35(1.18 \text { to } 1.55) \\
0.000\end{array}$ & $\begin{array}{l}0.82(0.65 \text { to } 1.03) \\
0.082\end{array}$ \\
\hline Employment status, n (\%) & 4162 & 1692 & 2076 & 394 & & & \\
\hline Employed & $1234(29.6)$ & $148(8.7)$ & $868(41.8)$ & $218(55.3) \dagger$ & 1 & 1 & 1 \\
\hline Inactive & $1935(46.5)$ & $1198(70.8)$ & $620(29.9)$ & $117(29.7)$ & $\begin{array}{l}15.08(11.37 \text { to } 19.99) \\
\mathbf{0 . 0 0 0}\end{array}$ & $\begin{array}{l}11.33 \text { (9.28 to } 13.83) \\
\mathbf{0 . 0 0 0}\end{array}$ & $\begin{array}{l}1.33(1.04 \text { to } 1.70) \\
\mathbf{0 . 0 0 0}\end{array}$ \\
\hline Unemployed & $993(23.9)$ & $346(20.4)$ & $588(28.3)$ & $59(15.0)$ & $\begin{array}{l}8.63(6.11 \text { to } 12.21) \\
\mathbf{0 . 0 0 0}\end{array}$ & $\begin{array}{l}3.45 \text { (2.77 to } 4.29) \\
0.000\end{array}$ & $\begin{array}{l}2.50(1.84 \text { to } 3.39) \\
\mathbf{0 . 0 2 3}\end{array}$ \\
\hline $\mathrm{BMI}, \mathrm{kg} / \mathrm{m}^{2}, \mathrm{n}$ & 4046 & 1660 & 2002 & 384 & 1.01 (0.99 to 1.03$)$ & 0.99 (0.97 to 1.02$)$ & 0.99 (0.97 to 1.02$)$ \\
\hline mean $(\mathrm{SD})$ & $26.60(5.00)$ & $26.70(5.37)$ & $26.50(4.57)$ & $26.70(5.16) \dagger$ & 0.225 & 0.620 & 0.611 \\
\hline $\mathrm{SBP}, \mathrm{mm} \mathrm{Hg}, \mathrm{n}$ & 4165 & 1694 & 2076 & 395 & $1.01(1.00$ to 1.01$)$ & 1.02 (1.01 to 1.02$)$ & 1.01 (1.00 to 1.02$)$ \\
\hline mean (SD) & $134.80(21.3)$ & $137.90(22.6)$ & $134.40(18.74)$ & $132.00(18.19) \dagger$ & 0.000 & 0.000 & 0.009 \\
\hline $\mathrm{DBP}, \mathrm{mm} \mathrm{Hg}, \mathrm{n}$ & 4165 & 1694 & 2076 & 395 & 1.01 (1.00 to 1.01$)$ & $1.02(1.01$ to 1.03$)$ & 1.01 (1.00 to 1.02$)$ \\
\hline mean (SD) & $83.70(11.41)$ & $84.80(11.76)$ & $83.82(10.78)$ & $82.58(10.82) \dagger$ & 0.048 & 0.000 & 0.013 \\
\hline $\mathrm{TC}, \mathrm{mg} / \mathrm{dL}, \mathrm{n}$ & 4059 & 1674 & 2003 & 382 & $1.00(0.95$ to 1.06$)$ & $1.04(0.95$ to 1.14$)$ & $1.02(0.94$ to 1.11$)$ \\
\hline mean (SD) & $5.12(1.40)$ & $5.11(1.38)$ & $5.12(1.40)$ & $5.10(1.33) \dagger$ & 0.891 & 0.393 & 0.566 \\
\hline $\mathrm{FBG}, \mathrm{mg} / \mathrm{dL}, \mathrm{n}$ & 4058 & 1674 & 2002 & 382 & 1.03 (0.98 to 1.08$)$ & 1.10 (1.01 to 1.20$)$ & 1.07 (0.98 to 1.16$)$ \\
\hline mean (SD) & $4.95(1.68)$ & $5.04(1.98)$ & $4.95(1.42)$ & $4.76(1.40) \dagger \S$ & 0.276 & 0.026 & 0.124 \\
\hline
\end{tabular}


Table 2 Prevalence of $\mathrm{CVH}$ metrics by educational level and association between health metrics and educational level

\begin{tabular}{|c|c|c|c|c|c|c|c|}
\hline \multirow[b]{2}{*}{ CVH metrics } & \multicolumn{4}{|c|}{ Educational level } & \multicolumn{3}{|c|}{ ORs, $95 \% \mathrm{Cl}$, p value† } \\
\hline & 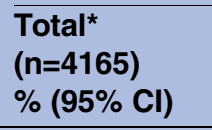 & $\begin{array}{l}\text { Low } \\
(n=1694)\end{array}$ & $\begin{array}{l}\text { Medium } \\
(\mathrm{n}=2076)\end{array}$ & $\begin{array}{l}\text { High } \\
(n=395)\end{array}$ & Low vs medium & Low vs high & Medium vs high \\
\hline Smoking status, $n$ & 4165 & 1694 & 2076 & 395 & & & \\
\hline Poor (current) & $\begin{array}{l}30.3 \\
(28.9 \text { to } 31.7)\end{array}$ & $\begin{array}{l}25.3 \\
(23.2 \text { to } 27.3)\end{array}$ & $\begin{array}{l}35.3 \\
(33.2 \text { to } 37.3)\end{array}$ & $\begin{array}{l}26.1 \\
(21.7 \text { to } 30.4)\end{array}$ & $\begin{array}{l}0.87 \\
(0.73 \text { to } 1.03) \\
0.116\end{array}$ & $\begin{array}{l}1.33 \\
(0.99 \text { to } 1.76) \\
0.051\end{array}$ & $\begin{array}{l}1.57 \\
(1.22 \text { to } 2.02) \\
\mathbf{0 . 0 0 1}\end{array}$ \\
\hline $\begin{array}{l}\text { Intermediate (former, quit } \\
<12 \text { months) }\end{array}$ & $\begin{array}{l}15.7 \\
(14.6 \text { to } 16.8)\end{array}$ & $\begin{array}{l}14.3 \\
(12.6 \text { to } 15.9)\end{array}$ & $\begin{array}{l}16.2 \\
(14.6 \text { to } 17.8)\end{array}$ & $\begin{array}{l}19.0 \\
(15.1 \text { to } 22.9)\end{array}$ & $\begin{array}{l}0.68 \\
(0.55 \text { to } 0.85) \\
\mathbf{0 . 0 0 1}\end{array}$ & $\begin{array}{l}0.74 \\
(0.53 \text { to } 1.03) \\
0.074\end{array}$ & $\begin{array}{l}1.14 \\
(0.84 \text { to } 1.53) \\
0.390\end{array}$ \\
\hline Ideal (never or quit >12 months) & $\begin{array}{l}54.0 \\
(52.5 \text { to } 55.5)\end{array}$ & $\begin{array}{l}60.4 \\
\text { (58.1 to } 62.8)\end{array}$ & $\begin{array}{l}48.6 \\
(46.4 \text { to } 50.7)\end{array}$ & $\begin{array}{l}54.9 \\
(50.0 \text { to } 59.8)\end{array}$ & 1 & 1 & 1 \\
\hline Body mass index, $n$ & 4039 & 1658 & 1998 & 383 & & & \\
\hline Poor $(\geq 30$ kg/m²) & $\begin{array}{l}21.3 \\
(20.0 \text { to } 22.5)\end{array}$ & $\begin{array}{l}25.9 \\
(23.7 \text { to } 27.9)\end{array}$ & $\begin{array}{l}17.9 \\
(16.2 \text { to } 19.5)\end{array}$ & $\begin{array}{l}19.1 \\
(15.1 \text { to } 23.0)\end{array}$ & $\begin{array}{l}1.10 \\
(0.89 \text { to } 1.35) \\
0.372\end{array}$ & $\begin{array}{l}0.99 \\
(0.72 \text { to } 1.39) \\
0.984\end{array}$ & $\begin{array}{l}1.02 \\
(0.74 \text { to } 1.39) \\
0.927\end{array}$ \\
\hline Intermediate $\left(25-29.9 \mathrm{~kg} / \mathrm{m}^{2}\right)$ & $\begin{array}{l}37.5 \\
(35.9 \text { to } 38.9)\end{array}$ & $\begin{array}{l}37.3 \\
(35.0 \text { to } 39.7)\end{array}$ & $\begin{array}{l}37.2 \\
(35.1 \text { to } 39.4)\end{array}$ & $\begin{array}{l}39.4 \\
(34.5 \text { to } 44.3)\end{array}$ & $\begin{array}{l}0.90 \\
(0.76 \text { to } 1.08) \\
0.263\end{array}$ & $\begin{array}{l}0.92 \\
(0.69 \text { to } 1.21) \\
0.536\end{array}$ & $\begin{array}{l}0.99 \\
(0.77 \text { to } 1.28) \\
0.966\end{array}$ \\
\hline Ideal $\left(<25 \mathrm{~kg} / \mathrm{m}^{2}\right)$ & $\begin{array}{l}41.2 \\
\text { (39.7 to } 42.3 \text { ) }\end{array}$ & $\begin{array}{l}36.8 \\
\text { (34.4 to } 39.1)\end{array}$ & $\begin{array}{l}44.9 \\
(42.7 \text { to } 47.1)\end{array}$ & $\begin{array}{l}41.5 \\
\text { (36.6 to } 46.4)\end{array}$ & 1 & 1 & 1 \\
\hline Physical activity level, $n$ & 4165 & 1694 & 2076 & 395 & & & \\
\hline Poor (inactive) & $\begin{array}{l}38.7 \\
(37.3 \text { to } 40.2)\end{array}$ & $\begin{array}{l}48.9 \\
(46.5 \text { to } 51.3)\end{array}$ & $\begin{array}{l}30.6 \\
(28.6 \text { to } 32.6)\end{array}$ & $\begin{array}{l}37.7 \\
(32.9 \text { to } 42.5)\end{array}$ & $\begin{array}{l}0.96 \\
(0.81 \text { to } 1.14) \\
0.655\end{array}$ & $\begin{array}{l}0.69 \\
(0.52 \text { to } 0.92) \\
\mathbf{0 . 0 1 0}\end{array}$ & $\begin{array}{l}0.74 \\
(0.58 \text { to } 0.96) \\
\mathbf{0 . 0 2 1}\end{array}$ \\
\hline Intermediate (moderately inactive) & $\begin{array}{l}20.0 \\
(18.8 \text { to } 21.3)\end{array}$ & $\begin{array}{l}15.5 \\
(13.7 \text { to } 17.2)\end{array}$ & $\begin{array}{l}23.1 \\
(21.3 \text { to } 24.9)\end{array}$ & $\begin{array}{l}23.8 \\
(19.6 \text { to } 28.0)\end{array}$ & $\begin{array}{l}0.85 \\
(0.69 \text { to } 1.05) \\
0.138\end{array}$ & $\begin{array}{l}0.66 \\
(0.48 \text { to } 0.91) \\
\mathbf{0 . 0 1 1}\end{array}$ & $\begin{array}{l}0.77 \\
(0.58 \text { to } 1.02) \\
0.068\end{array}$ \\
\hline Ideal (active) & $\begin{array}{l}41.2 \\
\text { (39.7 to } 42.7 \text { ) }\end{array}$ & $\begin{array}{l}35.6 \\
\text { (33.3 to } 37.9)\end{array}$ & $\begin{array}{l}46.3 \\
(44.2 \text { to } 48.5)\end{array}$ & $\begin{array}{l}38.5 \\
(33.7 \text { to } 43.3)\end{array}$ & 1 & 1 & 1 \\
\hline Healthy diet score, $n$ & 4165 & 1694 & 2076 & 395 & & & \\
\hline Poor $(<21)$ & $\begin{array}{l}61.0 \\
(59.5 \text { to } 62.5)\end{array}$ & $\begin{array}{l}56.3 \\
(53.9 \text { to } 56.9)\end{array}$ & $\begin{array}{l}66.2 \\
(64.1 \text { to } 68.2)\end{array}$ & $\begin{array}{l}54.2 \\
(49.2 \text { to } 59.1)\end{array}$ & $\begin{array}{l}1.67 \\
(1.14 \text { to } 2.43) \\
0.008\end{array}$ & $\begin{array}{l}3.49 \\
(2.10 \text { to } 5.83) \\
\mathbf{0 . 0 0 0}\end{array}$ & $\begin{array}{l}1.93 \\
(1.19 \text { to } 3.13) \\
0.000\end{array}$ \\
\hline Intermediate (21-25) & $\begin{array}{l}34.6 \\
(33.1 \text { to } 32.9)\end{array}$ & $\begin{array}{l}38.7 \\
(36.6 \text { to } 40.1)\end{array}$ & $\begin{array}{l}30.4 \\
(28.4 \text { to } 32.4)\end{array}$ & $\begin{array}{l}39.2 \\
(34.4 \text { to } 44.1)\end{array}$ & $\begin{array}{l}1.28 \\
(0.88 \text { to } 1.87) \\
0.200\end{array}$ & $\begin{array}{l}1.87 \\
(1.13 \text { to } 3.11) \\
\mathbf{0 . 0 1 4}\end{array}$ & $\begin{array}{l}1.34 \\
(0.82 \text { to } 2.18) \\
0.239\end{array}$ \\
\hline Ideal $(\geq 26)$ & $\begin{array}{l}4.4 \\
\text { (3.8 to } 5.0)\end{array}$ & $\begin{array}{l}5.1 \\
(4.0 \text { to } 6.1)\end{array}$ & $\begin{array}{l}3.4 \\
(2.6 \text { to } 4.2)\end{array}$ & $\begin{array}{l}6.6 \\
(4.1 \text { to } 9.0)\end{array}$ & 1 & 1 & 1 \\
\hline $\begin{array}{l}\text { Total cholesterol, } n \\
\text { Poor (>240 mg/dL) }\end{array}$ & $\begin{array}{l}4059 \\
20.8 \\
(19.6 \text { to } 22.1)\end{array}$ & $\begin{array}{l}1674 \\
26.3 \\
\text { (24.2 to } 28.4)\end{array}$ & $\begin{array}{l}2003 \\
17.0 \\
(15.3 \text { to } 18.6)\end{array}$ & $\begin{array}{l}382 \\
17.0 \\
(13.2 \text { to } 20.8)\end{array}$ & & & \\
\hline
\end{tabular}


Table 2 Continued

\begin{tabular}{|c|c|c|c|c|c|c|c|}
\hline \multirow[b]{2}{*}{ CVH metrics } & \multicolumn{4}{|c|}{ Educational level } & \multicolumn{3}{|c|}{ ORs, $95 \% \mathrm{Cl}$, p value $\dagger$} \\
\hline & $\begin{array}{l}\text { Total }^{*} \\
(\mathrm{n}=4165) \\
\%(95 \% \mathrm{Cl})\end{array}$ & $\begin{array}{l}\text { Low } \\
(n=1694)\end{array}$ & $\begin{array}{l}\text { Medium } \\
(\mathrm{n}=2076)\end{array}$ & $\begin{array}{l}\text { High } \\
(n=395)\end{array}$ & Low vs medium & Low vs high & Medium vs high \\
\hline & & & & & $\begin{array}{l}1.04 \\
(0.85 \text { to } 1.27) \\
0.719\end{array}$ & $\begin{array}{l}1.22 \\
(0.87 \text { to } 1.70) \\
0.241\end{array}$ & $\begin{array}{l}1.15 \\
(0.84 \text { to } 1.59) \\
0.384\end{array}$ \\
\hline $\begin{array}{l}\text { Intermediate }(200-239 \mathrm{mg} / \mathrm{dL} \text { or } \\
\text { treated to goal) }\end{array}$ & $\begin{array}{l}33.0 \\
(31.5 \text { to } 34.4)\end{array}$ & $\begin{array}{l}35.9 \\
(33.6 \text { to } 38.2)\end{array}$ & $\begin{array}{l}30.6 \\
(28.5 \text { to } 32.5)\end{array}$ & $\begin{array}{l}33.0 \\
(28.2 \text { to } 37.7)\end{array}$ & $\begin{array}{l}0.94 \\
(0.78 \text { to } 1.12) \\
0.470\end{array}$ & $\begin{array}{l}0.96 \\
(0.73 \text { to } 1.27) \\
0.784\end{array}$ & $\begin{array}{l}1.02 \\
(0.79 \text { to } 1.32) \\
0.883\end{array}$ \\
\hline Ideal (<200 mg/dL, untreated) & $\begin{array}{l}46.2 \\
(44.7 \text { to } 47.7)\end{array}$ & $\begin{array}{l}37.8 \\
(35.5 \text { to } 40.1)\end{array}$ & $\begin{array}{l}52.5 \\
(50.2 \text { to } 54.6)\end{array}$ & $\begin{array}{l}50.0 \\
(44.9 \text { to } 55.0)\end{array}$ & 1 & 1 & 1 \\
\hline Blood pressure, $\mathrm{n}$ & 4165 & 1694 & 2076 & 395 & & & \\
\hline Poor (SBP/DBP >140/90 mm Hg) & $\begin{array}{l}28.3 \\
(26.9 \text { to } 29.7)\end{array}$ & $\begin{array}{l}40.7 \\
(38.4 \text { to } 43.1)\end{array}$ & $\begin{array}{l}19.6 \\
(17.8 \text { to } 21.2)\end{array}$ & $\begin{array}{l}21.3 \\
(17.2 \text { to } 25.3)\end{array}$ & $\begin{array}{l}1.24 \\
(0.94 \text { to } 1.63) \\
0.131\end{array}$ & $\begin{array}{l}2.36 \\
(1.59 \text { to } 3.51) \\
0.000\end{array}$ & $\begin{array}{l}1.73 \\
(1.19 \text { to } 2.51) \\
0.004\end{array}$ \\
\hline $\begin{array}{l}\text { Intermediate (SBP } 120-139 \mathrm{~mm} / \\
\text { DBP } 80-89 \mathrm{~mm} \mathrm{Hg} \text {, or treated to } \\
\text { goal) }\end{array}$ & $\begin{array}{l}56.9 \\
(55.4 \text { to } 58.4)\end{array}$ & $\begin{array}{l}50.4 \\
(47.9 \text { to } 52.4\end{array}$ & $\begin{array}{l}62.3 \\
(60.2 \text { to } 64.7)\end{array}$ & $\begin{array}{l}57.0 \\
(52.1 \text { to } 61.9)\end{array}$ & $\begin{array}{l}0.84 \\
(0.66 \text { to } 1.07) \\
0.156\end{array}$ & $\begin{array}{l}1.48 \\
(1.06 \text { to } 2.07) \\
\mathbf{0 . 0 2 2}\end{array}$ & $\begin{array}{l}1.68 \\
(1.26 \text { to } 2.25) \\
0.000\end{array}$ \\
\hline $\begin{array}{l}\text { Ideal (SBP/DBP }<120 / 80 \mathrm{~mm} \mathrm{Hg} \text {, } \\
\text { untreated) }\end{array}$ & $\begin{array}{l}14.7 \\
\text { (13.7 to } 15.8)\end{array}$ & $\begin{array}{l}8.9 \\
(7.6 \text { to } 10.3)\end{array}$ & $\begin{array}{l}18.2 \\
(16.5 \text { to } 19.8)\end{array}$ & $\begin{array}{l}21.8 \\
(17.7 \text { to } 25.9)\end{array}$ & 1 & 1 & 1 \\
\hline Fasting blood glucose, $\mathrm{n}$ & 4058 & 1674 & 2002 & 382 & & & \\
\hline Poor (>126 mg/dL) & $\begin{array}{l}6.3 \\
(5.6 \text { to } 7.1)\end{array}$ & $\begin{array}{l}9.2 \\
(7.8 \text { to } 10.6)\end{array}$ & $\begin{array}{l}4.2 \\
(3.3 \text { to } 5.1)\end{array}$ & $\begin{array}{l}5.0 \\
(2.8 \text { to } 7.2)\end{array}$ & $\begin{array}{l}1.10 \\
(0.80 \text { to } 1.51) \\
0.546\end{array}$ & $\begin{array}{l}1.24 \\
(0.73 \text { to } 2.09) \\
0.420\end{array}$ & $\begin{array}{l}1.11 \\
(0.65 \text { to } 1.88) \\
0.711\end{array}$ \\
\hline $\begin{array}{l}\text { Intermediate }(100-125 \mathrm{mg} / \mathrm{dL} \text { or } \\
\text { treated to goal) }\end{array}$ & $\begin{array}{l}17.7 \\
(16.5 \text { to } 18.9)\end{array}$ & $\begin{array}{l}21.4 \\
(19.4 \text { to } 23.5)\end{array}$ & $\begin{array}{l}15.1 \\
(13.5 \text { to } 16.6)\end{array}$ & $\begin{array}{l}15.2 \\
(11.6 \text { to } 18.8)\end{array}$ & $\begin{array}{l}1.14 \\
(0.94 \text { to } 1.39) \\
0.192\end{array}$ & $\begin{array}{l}1.28 \\
(0.92 \text { to } 1.77) \\
0.141\end{array}$ & $\begin{array}{l}1.12 \\
(0.82 \text { to } 1.53) \\
0.477\end{array}$ \\
\hline Ideal (<100 mg/dL, untreated) & $\begin{array}{l}76.0 \\
(74.7 \text { to } 77.3)\end{array}$ & $\begin{array}{l}69.4 \\
(67.2 \text { to } 71.6)\end{array}$ & $\begin{array}{l}80.7 \\
(78.9 \text { to } 82.4) \\
\end{array}$ & $\begin{array}{l}79.8 \\
(75.8 \text { to } 83.9)\end{array}$ & 1 & 1 & 1 \\
\hline
\end{tabular}

${ }^{*}$ Prevalences in total, low, medium and high categories are adjusted on age and sex.

†According to logistic regression analysis. All comparisons of low (1) versus medium education group (0) and low (1) versus high education group (0) were adjusted for age and sex.

Comparisons of medium (1) versus high education group (0) were adjusted for age.

$\mathrm{CVH}$, cardiovascular health; DBP, diastolic blood pressure; SBP, systolic blood pressure. 
differences between the groups in the frequency of poor and intermediate levels of BMI, TC and FBG.

As shown in table 3 , it is worth noting that only $0.02 \%$ of study participants had all seven CVH metrics in the ideal range, and thus, virtually no one had ideal $\mathrm{CVH}$. In comparison to the low and medium education group those with high education had a higher value of the mean number of ideal cardiovascular metrics and ideal health factor metrics. However, there are no statistically significant differences in the ideal behaviours between participants in different educational groups. Poor CVH status (at least one poor health metric) was significantly more frequently seen in people with low and medium education, $94.7 \%$ and $91.4 \%$, respectively, in comparison with those with high education $(87.4 \%)$.

The results of subgroup analyses stratified by age and gender were presented in online supplementary appendix 2. In general, the relationship between the number of ideal $\mathrm{CVH}$ and $\mathrm{CVH}$ categories, and educational levels did not differ significantly in different age subgroups ( $\leq 18, \geq 20, \geq 25$ and $\leq 60$ years) with exceptions for study participants $\geq 25$ years only in the low versus high educational group. However, the analysis stratified by gender (for age subgroups $\leq 18, \geq 20$ and $\geq 25$ years) showed the differences between men and women. High-educated women had significantly greater numbers of ideal CVH metrics, ideal behaviour metrics and ideal health factor metrics compared with women with low or medium education, while low-educated men had greater numbers of ideal CVH metrics and ideal behaviour metrics only in comparison with medium-educated men (see online supplementary appendix 2).

\section{DISCUSSION}

Our study showed that the prevalence of ideal $\mathrm{CVH}$ in the general population of RS is extremely low $(0.02 \%)$, and that CVH is positively related to education-participants with high education had a better CVH profile in comparison with those with medium and low education. Our results are in accordance with the results from the world's largest population-based cross-sectional study performed in the 50 states of the USA. ${ }^{14}$ To our knowledge, only two European studies reported populationbased data on relationship between CVH (according to AHA criteria) and education. According to Graciani et $a l,{ }^{15}$ less-educated people have the worst $\mathrm{CVH}$, second only to the oldest. Olsen et $a l^{16}{ }^{16}$ using data from six cross-sectional studies conducted in an adult population aged 30-64 years in Denmark from 1978 to 2006 reported an increasing trend in ideal $\mathrm{CVH}$ with a more unfavourable risk profile among persons with low educational levels.

According to our results the mean number of ideal health factor metrics was statistically more frequently present in participants with high education in comparison to those with low and medium education, while the mean number of ideal health behaviours was more prevalent only in low-educated versus medium-educated persons.

Since poor CVH metrics are risk factors for CVD, it might be assumed that they follow the same socioeconomic pattern as CVD, with the higher prevalence among people of lower SES. This was confirmed for health behaviours in particular-lack of physical activity, poor nutrition and tobacco use in developed countries. ${ }^{17-20}$ However, the evidence from developing countries has been inconsistent. Some studies have indicated that SES is inversely associated with the level of cardiovascular risk factors, ${ }^{21-23}$ whereas there are studies revealing an entirely opposite trend. ${ }^{24}{ }^{25}$ In addition, there is scant information on social patterning of CVD risk factors in residents from developing countries still in transition, such as RS.

Our research has shown that while some CVH metrics (diet behaviour, SBP and DBP) follow the same socioeconomic gradient as CVD, several other health metrics do not. For example, neither smoking behaviour nor physical activity levels are consistently related to education. There is strong evidence of social patterning of smoking not only in developed, but also in some developing countries where epidemiological transition is undergoing or has already occurred. ${ }^{26-28}$ However, we failed to find any statistically significant difference in smoking between high and low educational groups. It is worth noting that in Southern European regions smoking seems to be more related to cultural norms than to socioeconomic factors and weak or inexistent socioeconomic gradients were frequently reported. ${ }^{29}$ Higher levels of blood pressure in low-educated people could be explained by poor diet and lack of health education in this group..$^{30}$ According to our results, participants with low education, after adjusting for age and sex were less frequently physically inactive, that is in accordance with a large study from rural India. ${ }^{22}$ In contrast, findings from developed countries showed positive association between vigorous physical activity carried out at leisure time and educational level. ${ }^{31}{ }^{32}$ An inverse association between BMI and education level was found in most studies: individuals in the low socioeconomic groups had higher BMIs than those in the high socioeconomic groups. ${ }^{33} 34$ We failed to find any statistically significant difference between education and BMI. However, as in the majority of reviewed studies, ${ }^{22} 35$ we found an inverse association between education and unhealthy diet. Differences in the social patterning of unhealthy behaviours in developing countries can be related to cultural differences between them. Another plausible explanation might be differences in the epidemiological transition from 'diseases of affluence' to the diseases of the poor. ${ }^{36}$ For example, smoking and unhealthy eating were, once, more common among the better-off. ${ }^{30}$

Studies of gender differences in the association between SES and cardiovascular risk factors have produced mixed findings. Recently Jenkins and Ofstedal ${ }^{37}$ have observed that lower SES was associated with higher 
Table 3 Association between number of ideal cardiovascular health $(\mathrm{CVH})$ metrics and $\mathrm{CVH}$ categories, and educational level

\begin{tabular}{|c|c|c|c|c|c|c|c|}
\hline & \multirow{3}{*}{$\begin{array}{l}\begin{array}{l}\text { Total } \\
(\mathrm{n}=4015) \\
100.0 \%\end{array} \\
\end{array}$} & \multicolumn{6}{|l|}{ Educational level } \\
\hline & & \multirow{2}{*}{$\begin{array}{l}\text { Low } \\
(n=1651) \\
41.1 \%\end{array}$} & \multirow{2}{*}{$\begin{array}{l}\text { Medium } \\
(n=1984) \\
49.4 \%\end{array}$} & \multirow{2}{*}{$\begin{array}{l}\text { High } \\
(n=380) \\
9.5 \%\end{array}$} & \multicolumn{3}{|c|}{ ORs, $95 \% \mathrm{Cl}$, p value† } \\
\hline & & & & & Low vs medium & Low vs high & Medium vs high \\
\hline $\begin{array}{l}\text { Number of ideal CVH metrics, } \\
\text { mean (SE) } \\
\text { median (IQR) }\end{array}$ & $\begin{array}{l}2.78(0.02) \\
3.00(2.00)\end{array}$ & $\begin{array}{l}2.76(0.03) \\
2.00(1.00)\end{array}$ & $\begin{array}{l}2.77(0.03) \\
3.00(2.00)\end{array}$ & $\begin{array}{l}2.93(0.06) \\
3.00(2.00)\end{array}$ & $\begin{array}{l}0.99(0.92 \text { to } 1.06) \\
0.802\end{array}$ & $\begin{array}{l}0.88(0.77 \text { to } 0.99) \\
\mathbf{0 . 0 3 3}\end{array}$ & $\begin{array}{l}0.88(0.80 \text { to } 0.96) \\
\mathbf{0 . 0 0 9}\end{array}$ \\
\hline $\begin{array}{l}\text { Number of ideal behaviours, } \\
\text { mean (SE) } \\
\text { median (IQR) }\end{array}$ & $\begin{array}{l}1.41(0.02) \\
1.00(1.00)\end{array}$ & $\begin{array}{l}1.42(0.02) \\
1.00(1.00)\end{array}$ & $\begin{array}{l}1.38(0.02) \\
1.00(1.00)\end{array}$ & $\begin{array}{l}1.45(0.04) \\
1.00(1.00)\end{array}$ & $\begin{array}{l}1.03(0.93 \text { to } 1.13) \\
0.560\end{array}$ & $\begin{array}{l}0.94(0.78 \text { to } 1.11) \\
0.453\end{array}$ & $\begin{array}{l}0.92(0.81 \text { to } 1.04) \\
0.198\end{array}$ \\
\hline $\begin{array}{l}\text { Number of ideal health factors, } \\
\text { mean (SE) } \\
\text { median (IQR) }\end{array}$ & $\begin{array}{l}1.95(0.02) \\
2.00(2.00)\end{array}$ & $\begin{array}{l}1.91(0.02) \\
2.00(1.00)\end{array}$ & $\begin{array}{l}1.89(0.02) \\
2.00(2.00)\end{array}$ & $\begin{array}{l}2.07(0.05) \\
2.00(2.00)\end{array}$ & $\begin{array}{l}1.01(0.93 \text { to } 1.11) \\
0.746\end{array}$ & $\begin{array}{l}0.81(0.69 \text { to } 0.96) \\
\mathbf{0 . 0 1 2}\end{array}$ & $\begin{array}{l}0.77(0.68 \text { to } 0.87) \\
\mathbf{0 . 0 0 0}\end{array}$ \\
\hline $\begin{array}{l}\text { Category of } \mathrm{CVH}, \%(95 \% \mathrm{Cl}) \\
\text { Ideal CVH }\end{array}$ & 0.02 & & & & & & \\
\hline Intermediate $\mathrm{CVH} \S$ & $7.6(6.8$ to 8.4$)$ & $5.3(4.3$ to 6.4$)$ & $8.6(7.3$ to 9.8$)$ & $12.4(9.0$ to 15.7$)$ & 1 & 1 & 1 \\
\hline Poor CVHף & 92.4 (91.6 to 93.2$)$ & 94.7 (93.6 to 95.8$)$ & $91.4(90.2$ to 92.7$)$ & 87.4 (84.0 to 90.7$)$ & $\begin{array}{l}1.22(0.87 \text { to } 1.68) \\
0.242\end{array}$ & $\begin{array}{l}1.93(1.24 \text { to } 3.01) \\
\mathbf{0 . 0 0 4}\end{array}$ & $\begin{array}{l}1.54(1.08 \text { to } 2.19) \\
0.015\end{array}$ \\
\hline
\end{tabular}

${ }^{*}$ Means in total, low, medium and high categories are adjusted on age, sex, marital status, employment status and type of settlement. Prevalences are adjusted on age and sex.

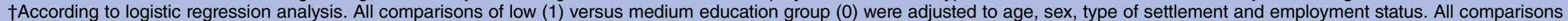

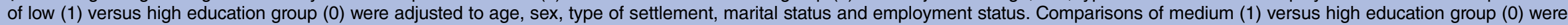
adjusted to age, type of settlement and employment status.

fldeal health is all seven health metrics at ideal levels.

§Intermediate health is at least one health metric at intermediate level, but no poor health metrics.

IPoor health is at least one of seven health metrics at a poor level. 
cardiovascular risk for middle-aged and older women but not for men. According to Olsen et al, ${ }^{16}$ a 28-year trend for women aged 30-64 years showed an increasing proportion in ideal CVH with a more unfavourable risk profile among women with a low educational level, while for men the educational difference was less pronounced. In our study low-educated and medium-educated women had significantly smaller number of ideal $\mathrm{CVH}$ metrics, ideal behaviour metrics and ideal health factor metrics compared with women with high education, while low-educated men in comparison with medium-educated men had a greater number of ideal CVH metrics and ideal behaviours. Our findings suggest that the association between SES and cardiovascular risk is more pronounced for women than it is for men. Implementing interventions to increase CVH, particularly among women with lower SES, might reduce CVD in women in RS.

The main strength of this study is the large sample representative of the population of RS aged $\geq 18$ years. However, we note several limitations. The cross-sectional design of our study makes it difficult to judge causal relations. We exclusively focused on education as the main indicator of SES, because it is established relatively early in life, and it is stable over the adult lifespan, allows classification of individuals who do not work and prevents reverse causation. Further, the information on smoking, physical activity, diet and treatment (for hypertension, diabetes mellitus and hypercholesterolaemia) was self-reported and may be subject to recall bias. Calculations for food scores may have been biased due to misreporting by older participants with poor memory or under-reporting by those who were overweight or obese. There is a possibility of measurement error caused by participants with high education intentionally or unintentionally reporting a healthier diet because they knew it was more socially acceptable. Notwithstanding these limitations, our results indicate positive association between CVH and education, although the SES pattern in CVD is not mirrored by similar SES patterns in all CVH metrics. Some CVH metrics were worse in higher SES participants while others were worse in lower SES groups.

Overall, the present study emphasises the large potential for preventing CVD, showing a low proportion with a favourable CVH profile, especially among low-educated people. Since it is well known that individuals with the highest education are more likely to act on prevention campaigns, ${ }^{38}$ it is necessary to consider prevention strategies aimed in improving CVH in RS targeting primarily low educational groups.

\footnotetext{
Author affiliations

${ }^{1}$ Faculty of Medicine, Institute of Epidemiology, University of Belgrade, Belgrade, Serbia

${ }^{2}$ Institute of Public Health Republic of Srpska, Banja Luka, Bosnia and Herzegovina

${ }^{3}$ Faculty of Medicine, Institute of Social Medicine, University of Belgrade, Belgrade, Serbia
}

${ }^{4}$ Faculty of Economics, Finance and Administration, Singidunum University, Belgrade, Serbia

${ }^{5}$ Faculty of Medicine, Institute of Medical Statistics and Informatics, University of Belgrade, Belgrade, Serbia

Contributors JM designed and conducted the statistical analysis and contributed to the writing of the first draft of the manuscript. SJ drafted the manuscript, and is the guarantor. DS and ME performed the data cleaning and contributed to the statistical analysis. $\mathrm{JJ}$ contributed to the design of the study. All authors revised the draft manuscript, provided critical comments and approved the final version of the manuscript. All authors were included in the major revision of the manuscript and approved the current version.

Funding This study was supported by the World Bank and Ministry of Health and Social Welfare of the Republic of Srpska; and the Ministry of Education, Science and Technological Development of the Republic of Serbia (project No. 175025).

\section{Competing interests None.}

Ethics approval The study was approved by the Ethics Committee of the Public Health Institute of Republic of Srpska.

Provenance and peer review Not commissioned; externally peer reviewed.

Data sharing statement No additional data are available.

Open Access This is an Open Access article distributed in accordance with the Creative Commons Attribution Non Commercial (CC BY-NC 4.0) license, which permits others to distribute, remix, adapt, build upon this work noncommercially, and license their derivative works on different terms, provided the original work is properly cited and the use is non-commercial. See: http:// creativecommons.org/licenses/by-nc/4.0/

\section{REFERENCES}

1. World Health Organization. Global status report on noncommunicable diseases 2010. Geneva: World Health Organization, 2011.

2. Mathers CD, Loncar D. Projections of global mortality and burden of disease from 2002 to 2030. PLoS Med 2006;3:e442.

3. Marinković D, Majić A. Promjene u mortalitetu stanovništva Republike Srpske u periodu 1996-2010. godine-faktori i posljedice [Changes in mortality of the Republic of Srpska population in the period 1996 to 2010 - causes and consequences] (in Serbian). Demography 2012;9:27-44.

4. Lloyd-Jones DM, Hong Y, Labarthe D, et al.; American Heart Association Strategic Planning Task Force and Statistics Committee. Defining and setting national goals for cardiovascular health promotion and disease reduction: the American Heart Association's strategic impact goal through 2020 and beyond. Circulation 2010;121:586-613.

5. Yang Q, Cogswell ME, Flanders WD, et al. Trends in cardiovascular health metrics and associations with all-cause and CVD mortality among US adults. JAMA 2012;307:1273-83.

6. Folsom AR, Yatsuya $\mathrm{H}$, Nettleton JA, et al. Community prevalence of ideal cardiovascular health, by the American Heart Association definition, and relationship with cardiovascular disease incidence. J Am Coll Cardiol 2011;57:1690-6.

7. Mackenbach JP, Cavelaars AE, Kunst AE, et al. Socioeconomic inequalities in cardiovascular disease mortality; an international study. Eur Heart J. 2000;21:1141-51.

8. Mackenbach JP, Stirbu I, Roskam AJ, et al.; European Union Working Group on Socioeconomic Inequalities in Health. Socioeconomic inequalities in health in 22 European countries. N Engl J Med 2008;358:2468-81.

9. National public health institute (KTL). Finbalt health monitor. Shared English version of the questionnaire of year 2004 as decided by the meeting in Helsinki October 10, 2007. KTL, 2008:5-7. http://www.thl fi/thl-client/pdfs/54480690-8e81-4393-ba1a-e9999a1f375a (accessed June 2014).

10. Matović-Miljanović S, Grozdanov J, Božanić V, et al. Istraživanje zdravlja stanovništva Republike Srpske. Izvještaj o rezultatima istraživanja. Prilog 2 [Population health survey in Republic of Srpska. Report. Appendix 2] (in Serbian). Banja Luka: Public Health Institute of the Republic of Srpska, 2011.

11. Stojisavljević D, Danojević D, Bojanić J, et al. Vodič za pravilnu ishranu za zdravstvene profesionalce [Guide for proper nutrition for health care professionals] (in Serbian). Banja Luka: Public Health Institute of Republic of Srpska, 2005:18-27. 
12. Rapi S, Bazzini C, Tozzetti C, et al. Point-of-care testing of cholesterol and triglycerides for epidemiologic studies: evaluation of the multicare-in system. Trans/ Res 2009;153:71-6.

13. Priya M, Mohan Anjana R, Pradeepa R, et al. Comparison of capillary whole blood versus venous plasma glucose estimations in screening for diabetes mellitus in epidemiological studies in developing countries. Diabetes Technol Ther 2011;13:586-91.

14. Fang J, Yang Q, Hong $Y$, et al. Status of cardiovascular health among adult Americans in the 50 States and the District of Columbia, 2009. J Am Heart Assoc 2012;1:e005371.

15. Graciani A, León-Muñoz LM, Guallar-Castillón $P$, et al. Cardiovascular health in a southern Mediterranean European country: a nationwide population-based study. Circ Cardiovasc Qual Outcomes 2013;6:90-8.

16. Olsen GS, Holm AS, Jørgensen T, et al. Distribution of ideal cardiovascular health by educational levels from 1978 to 2006: a time trend study from the capital region of Denmark. Eur J Prev Cardiol Published Online First: 11 April 2013. doi: 10.1177/ 2047487313485513.

17. Lawlor DA, Batty GD, Morton SM, et al. Childhood socioeconomic position, educational attainment, and adult cardiovascular risk factors: the Aberdeen children of the 1950s cohort study. Am J Public Health 2005;95:1245-51.

18. Blane D, Hart CL, Smith GD, et al. Association of cardiovascular disease risk factors with socioeconomic position during childhood and during adulthood. BMJ 1996;313:1434-8.

19. Strand BH, Tverdal A. Trends in educational inequalities in cardiovascular risk factors: a longitudinal study among 48,000 middle-aged Norwegian men and women. Eur J Epidemiol 2006;21:731-9.

20. Laaksonen M, Talala K, Martelin T, et al. Health behaviours as explanations for educational level differences in cardiovascular and all-cause mortality: a follow-up of 60000 men and women over 23 years. Eur J Public Health 2008;18:38-43.

21. Yu Z, Nissinen A, Vartiainen E, et al. Associations between socioeconomic status and cardiovascular risk factors in an urban population in China. Bull World Health Organ 2000;78:1296-305.

22. Gupta R, Kaul V, Agrawal A, et al. Cardiovascular risk according to educational status in India. Prev Med 2010;51:408-11.

23. Zaman MJ, Patel A, Jan S, et al. Socio-economic distribution of cardiovascular risk factors and knowledge in rural India. Int $J$ Epidemiol 2012;41:1302-14.

24. Pereira MA, Kriska AM, Collins VR, et al. Occupation status and cardiovascular disease in the rapidly developing, high-risk population of Mauritius. Am J Epidemiol 1998;148:148-59.
25. Yu Z, Nissinen A, Erkki Vartiainen E, et al. Changes in cardiovascular risk factors in different socioeconomic groups: seven year trends in a Chinese urban population. J Epidemiol Community Health 2000;54:692-6.

26. Gupta R. Smoking, educational status and health inequity in India. Indian J Med Res 2006;124:15-22.

27. Samuel $\mathrm{P}$, Antonisamy $\mathrm{B}$, Raghupathy $\mathrm{P}$, et al. Socio-economic status and cardiovascular risk factors in rural and urban areas of Vellore, Tamilnadu, South India. Int J Epidemiol 2012;41:1315-27.

28. Murphy GA, Asiki G, Ekoru K, et al. Sociodemographic distribution of non-communicable disease risk factors in rural Uganda: a cross-sectional study. Int J Epidemiol 2013;42:1740-53.

29. Stringhini S, Dugravot A, Shipley M, et al. Health behaviours, socioeconomic status, and mortality: further analyses of the British Whitehall II and the French GAZEL prospective cohorts. PLoS Med 2011;8:e1000419.

30. Reddy KS, Katan MB. Diet, nutrition and the prevention of hypertension and cardiovascular diseases. Public Health Nutr 2004;7:167-86.

31. Meyer K, Rezny L, Breuer C, et al. Physical activity of adults aged 50 years and older in Switzerland. Soz Praventivmed 2005;50:218-29.

32. Singh GK, Kogan MD, Siahpush M, et al. Independent and joint effects of socioeconomic, behavioral, and neighborhood characteristics on physical inactivity and activity levels among US children and adolescents. J Community Health 2008;33:206-16.

33. Hermann S, Rohrmann S, Linseisen J, et al. The association of education with body mass index and waist circumference in the EPIC-PANACEA study. BMC Public Health 2011;11:169.

34. Dugravot A, Sabia S, Stringhini S, et al. Do socioeconomic factors shape weight and obesity trajectories over the transition from midlife to old age? Results from the French GAZEL cohort study. Am J Clin Nutr 2010;92:16-23.

35. Pilic L, Dzakula A. Socioeconomic status and risky health behaviors in Croatian adult population. Acta Med Croatica 2013;67:25-35.

36. Yusuf S, Reddy S, Ounpuu S, et al. Global burden of cardiovascular diseases: part I: general considerations, the epidemiologic transition, risk factors, and impact of urbanization. Circulation 2001:104:2746-53.

37. Jenkins KR, Ofstedal MB. The association between socioeconomic status and cardiovascular risk factors among middle-aged and older men and women. Women Health 2014:54:15-34.

38. Clark AM, DesMeules M, Luo W, et al. Socioeconomic status and cardiovascular disease: risks and implications for care. Nat Rev Cardiol 2009;6:712-22. 